\title{
Representation of Violence and Trauma in Contemporary Monologues
}

\section{Hana Pavelková}

Contrary to the rapid frenzied dialogues and confrontational brutal physical scenes showing acute pain in the "in-yer-face" theatre of the 19gos, contemporary political dramas very often opt for a purely verbal, verbatim, evocation of violence. This paper focuses on the representation of violence and the ensuing trauma specifically in plays that use a monologue format. The range of contemporary monologues is demonstrated firstly by analysing the media-popular, political awareness-raising, straightforward personal narratives of the documentary monologue My Name is Rachel Corrie (eds. Alan Rickman and Katharine Viner, 2005) and Eve Ensler's The Vagina Monologues (1998), to the much more complex and audience challenging Nine Parts of Desire (2003) by Heather Raffo, and Doug Wright's Pulitzer Prize winning monodrama I Am My Own Wife (2004) which questions the reliability of its monologist and examines also the limits of the theatrical monologue as a means of communicating trauma via verbal representation of violence.

Cannibalism, masturbation, rape, bodily mutilations, defecation, disembowelment, oceans of blood and non-stop swearing - that was British theatre in 1990 os London - "in-yer-face" theatre. In the new millennium, however, especially after $9 / 11$, the theatre scene has changed significantly, the return of political theatre and documentary theatre being the two most visible trends. Although we cannot speak about any artistic movement, the playwrights of "in-yer-face" theatre shared a common sensibility. Extreme violence, both verbal and visual, was undoubtedly one of their trademarks. The authors of political dramas, mainly docudramas, employ scenes of extreme violence as well, but in a different way. Contrary to the rapid frenzied dialogues and confrontational brutal physical scenes showing acute pain of "in-yer-face" theatre, the contemporary political dramas very often opt for the purely verbal, verbatim, evocation of violence. This paper will focus on the representation of violence and the ensuing trauma specifically in plays that use a monologue format and that have caused significant media scandals: the documentary monologue My Name is Rachel Corrie (eds. Alan Rickman and Katharine Viner, 
2005) and Eve Ensler's The Vagina Monologues (1998). Heather Raffo's Nine Parts of Desire (2003) might serve as a contrast to straight forward political activism and Doug Wright's monodrama I Am My Own Wife (2004) even questions the reliability of its monologist, therefore the paper will examine also the limits of the theatrical monologue as a means of communicating trauma via verbal representation of violence.

One of the advantages of a theatrical monologue is that it gives a voice to the voiceless and provides the previously silenced narrators with the opportunity to share their stories. Since the 1990s monologues have become increasingly confessional, experiential and experimental in order to establish an intimate contact with the audience. Paradoxically, as Rebecca D'Monté pointed out, "whilst this would suggest a dramatic form that empowers, the subject matter frequently focuses on physical and mental abuse" (209). If really experiential, such theatre should "aim to give audiences the experience of actually having lived through the actions depicted on stage. But not literally! Instead of allowing spectators to just sit back and contemplate the play, experiential theatre grabs its audiences and forces them to confront the reality of the feelings shown to them" (In Yer Face Theatre). In other words, experiential theatre wants to "get the guests", as George and Martha did in Albee's Who's Afraid of Virginia Woolf and cause an intense feeling of discomfort, "drawing the attention to the experience itself" (Rebellato 209).

Not all of the playwrights of the monologue plays to be discussed have succeeded equally in creating the desired effect. The first monologue play $M y$ Name is Rachel Corrie is arguably not so very accomplished theatrically, but has undoubtedly had an extraordinary effect off stage. Its cancellation initiated a heated debate about censorship and political correctness and drew the attention of the general public to the real case of Rachel Corrie. As mentioned above, My Name Is Rachel Corrie is a documentary monologue. It is based on the emails and diaries of a 23-year-old American Pro-Palestinian activist Rachel Corrie, who was killed by an Israeli bulldozer while defending a Palestinian home. The Corrie family later brought a civil claim for negligence against the Israeli ministry of defence, and the trial took almost three years. However, in August 2012 the judge said "the 23-year-old's death was a 'regrettable accident' and that the state was not responsible" (Donnison).

Alan Rickman and Katharine Viner with the permission of the Corrie family edited Rachel's emails and the play opened in London at the Royal Court Theatre in 2005 and was subsequently presented in the West End and on tour throughout the UK. The reviews were unanimously positive, praising 
the play for being "funny, passionate, bristling with idealism and luminously intelligent" (My Name Is Rachel Corrie). The Guardian even suggested that " $[\mathrm{t}]$ heatre cannot change the world. But what it can do, when it is as good as this, is to send us out enriched by other people's passionate concerns" (My Name Is Rachel Corrie).

In contrast, the reception of the play in the USA was very different. On 27 February 2006, the New York Theatre Workshop withdrew its upcoming production of My Name Is Rachel Corrie because they were worried about the reaction of the local community. Such a decision seems paradoxical from a theatre that describes its mission as: "to develop and produce theatrical experiences that reflect and respond to the world around us and re-invigorate the artists and audiences we connect with each year" (New York Theatre Workshop). Its artistic director, James Nicola, explained that by staging My Name Is Rachel Corrie at the time of the Israel-Lebanon war (winter 2006) and also at the time of protests in the Arab world against the Muhammad caricatures, it would put their theatre in a position they did not want it to be. Nicola argued that "[i]n the current climate the work could not be appreciated as 'art' but would be seen in political terms" (Davies 6). His noncommittal argumentation and the cancellation of the production caused a furore in the media and Nicola was rightly accused of censorship.

Watching the play, or reading it - it might actually be surprising that it could have caused such reactions - both such praise and such paranoia. Although Rachel Corrie probably had the ambition to become a writer, her emails and diaries are quite banal, it is "only" the fact that it is a real life story with a tragic ending that makes the play work. Rickman's and Viner's choice of the quasi-naturalistic monologue form is just the easiest way to convey the message. As Walter A. Davies commented, "Rachel is primarily a self-assured speaker, not a traumatized existential subject, and with Rickman's and Viner's aid she remains true to her rhetorical task. To preach messages" (27). Davies is wishing for a more imaginative approach to the topic and he rightly says that "[i]t is a slight piece, worthy enough for a minor night of theatre if seen in terms of its considerable limitations, but profoundly unsatisfying, even retrograde, if regarded as a complex realization of either the art of monologue or the mission of 'progressive' theatre" (27).

Yet, despite its limitations My Name Is Rachel Corrie succeeded in engaging with the audience. Because of the controversies caused by its cancellation and all the media debates about censorship and political correctness (this was still in the era of George W. Bush), it provoked an unusual public response, which 


\section{HANA PAVELKOVÁ}

included, for example, the creation of a web page called Rachel Corrie Facts, where people could present other points of view, add information that was omitted from the play, etc. The lively debate took on a life of its own. The play eventually made it on stage even in New York, but in a different theatre - in October 2006 it had its American premiere at Minetta Lane Theatre and there were no protests, and no controversies from the local community. Ironically, it became a box office hit.

The final success of My Name Is Rachel Corrie, however, is relatively small in comparison with the enormous appeal of Eve Ensler. At the time of its premiere in 1998, when Ensler performed The Vagina Monologues as her solo show in a small Off-Broadway theatre, the title itself was daring. Since then this series of confessional monologues based on Ensler's interviews with more than 200 women, has changed from a mere dramatic script to a global mass culture event. The Vagina Monologues was translated into 48 languages and performed in 140 countries all over the world. Furthermore, this play inspired the V-Day Movement - a charitable organization aiming to stop violence against women and girls. The organization raises money through beneficial performances of The Vagina Monologues both as productions with celebrities and professional actors, but importantly also as amateur college productions with students. The success and universal acclaim of the play is, in Ensler's words, "based on women's ability to speak their truth about violence in a way that liberates, rather than condemns, and frees both the spirit and political will" (Ensler 176). Eve Ensler and the V-Day Movement have no small goals - they are trying to go global and help women all over the world. In their view, "we must hear each other's stories to understand each other, that understanding thus fuels anger, compassion, and a sense of shared mission to foster change for the better in our lives and the world" (Cooper 1). Their recipe for success is seductively simple: "The last three decades of feminism were also marked by a deep anger as the truth of violence against the female body was revealed. [...] Women's sanity was saved by bringing these hidden experiences into the open, naming them, and turning our rage into positive action to reduce and heal violence" (Ensler $\mathrm{xv}$ ). In other words, the universal cure for all victims of violence seems to be confession, a coming-out, a representation, a verbalization of their traumas in front of an attentive audience; a compassionate community.

However, is such a community created by purchasing theatre tickets, by attending celebrity packed gala performances or by buying a DVD with Ensler's special performance of the show as part of HBO V-Day season? In other words, how is it possible that a play with such a title and arguably with 
such a controversial topic has become mainstream, a mass culture commodity, when, theoretically, its purpose is to be taboo breaking and challenging, "creating a visceral shift in consciousness?" (Ensler 176). The answer, in my opinion, is that although Ensler is not a particularly good playwright, nor performer, she knows how to attract wide audiences. It is the very form of The Vagina Monologues that does the trick. Not only does she address the audience directly, she seduces them by the confessional mode of her performance. It is either her physical presence on stage in the productions she performs herself, or the character of the dramatist which is present on the page of the script, that makes the play accessible. The autobiographical dimension is crucial to all confessional monologues as it creates the desired effect of authenticity and supports the credibility of the performance. It is the monological form that enables such manipulation. On the surface, Ensler is self-reflective, she shares not only the stories she heard from the women she interviewed, but also her own concerns and traumas, both as a woman and as a playwright. The opening scene of The Vagina Monologues is a good example of Ensler's technique:

I bet you are worried. I was worried. That's why I began this piece. I was worried about vaginas. I was worried about what we think about vaginas, and even more worried that we don't talk about them. I was worried about my own vagina. It needed a context of other vaginas - a community, a culture of vaginas. $(3$, emphasis in original $)$

For the audience, the opening remark "I bet you are worried' plays as much on the anxiety aroused by attending the show as on the concern about vaginas Ensler wishes to instil"(3), as Christine M. Cooper rightly commented. Moreover, the frequency with which the key word appears is no coincidence. Perhaps originally intended as a shocker, by now the audience know that the play is going to be experiential and that "the word 'cunt' will be yelled fervently during the evening, with audience participation expected" (Cooper 3). Another thing Ensler does from the very beginning is to make her audience feel comfortable. She paradoxically smoothes down the edges of the possible controversy or the shock for the audience by softening the play with humour. The initial embarrassment of the audience, which is quite natural, is welcomed and soothed with shy smiles and merry laughter. Ensler titillates her audience with vivid descriptions of the most intimate details. It is the speech, the naming and sharing in public that empowers the speakers and indirectly also the listeners. At one instance, in the section called "The woman who loved to 
make vaginas happy", a lesbian sex worker explains how she loves making women happy and demonstrates various kinds of orgasmic moans:

when performed well the monologue is a tour de force: hilarious for the surprising turns it takes and for the possible identification viewers can make between it and some part of themselves. It aims to represent a womencentred pleasure, where the sex worker releases from every client her own 'power moan'. Stage productions end here, with this warm, egalitarian utopia of fully realized and fully satisfied female desire. (Cooper 14-15)

By the end of the performance, the feel-good, celebratory atmosphere is shared by everyone at the theatre. But has The Vagina Monologues achieved its mission? Is it really possible for a confessional monologue in such form to "create a visceral shift in consciousness" and "heal violence" when the viewers are constantly reassured in their comfortable position?

Heather Raffo's play Nine Parts of Desire, on the other hand, is far more successful in communicating trauma in a much more disconcerting way. The viewers are not patted on their shoulders, but forced to relive the horrors of the victims. Straightforward activism or a call for positive action is not present because Raffo's play engages with the audience on a more subtle and deeper level. As she explains:

As an Iraqi American I feel enormous responsibility and I thought it would be great for me to create a story that could allow American audience to do what they do best, which is to have a heartfelt approach to the Iraqi people rather than a political way of looking at it. Each night performing it I have to emotionally go to Iraq to make these women justice. (Raffo)

Nine Parts of Desire is a monologue play as well as a poem, partly inspired by real life events and based on real people Raffo met, but the core of the play is imaginary. The nine women Raffo enacts are from Iraq, one of them being an Iraqi-American like Heather Raffo herself. The play was written in 2004, when the second war in Iraq was still in its full swing, yet what is striking about this play is that contrary to most works dealing with this topic and mainly criticizing the U.S. for the intervention, Raffo includes in her play also other points of view. The horrors caused by the war are presented as definitely devastating, but the horrific crimes of Saddam's regime are seen as equally traumatic for the people of Iraq. When described from the perspective of 
the women, who lost their relatives, were imprisoned, tortured, raped, forced into emigration, but importantly who also still have their love lives in front of them, go to work, want to study or are trying to help, the audience get a personalized, subjective and intimate portrait of the complex situation in Iraq that is quite rare and definitely not available in the media.

Despite many differences, Raffo's technique shares some common features with Ensler - paradoxically it is again the use of humour, which might seem surprising given the seriousness of the theme and the gravity of the horrors depicted. There are some passages that are comic, for example, in one scene Raffo plays a little girl who is dancing in front of a TV with a video clip of her favourite music band N'Sync and tells a story about the American soldiers who came to her school and interested her very much because one of them looked like Justin Timberlake. Most other scenes, however, are very drastic, full of scary and hideous details, such as the story of a girl raped by Saddam's son Uday, who later covered her in honey and watched his Dobermans tear her to pieces and eat her. Or prisoners boiled alive in hot water with only their nails and hair remaining glued to the walls above water level. The dead victims cannot speak, but the survivors do. The women manage to find the words to tell their stories, however fragmented and incomplete they are. Despite all the horrors, they try to communicate their trauma, but are well aware of their hopelessness, such as the character of the Iraqi-American, who cannot connect with her relatives in Iraq and is paralyzed just watching the TV with the live coverage of the war and ritualistically repeating the names of her family like a mantra.

Although Heather Raffo succeeds in creating a devastating emotional experience for the audience, that arguably has the power to "create a visceral shift in consciousness", she still presents the trauma caused by violence as something that might be put into words, communicated and shared. In contrast, Doug Wright does not stop there. He not only gives voice to the voiceless - an East German transvestite who survived the horrors of both Nazism and Communism - but he questions the reliability of such personal, subaltern narratives. In other words, his monologist, though still privileged by being the only voice to be heard from the stage, does not remain unchallenged. Michael R. Schiavi aptly comments that the popularity and the enormous success of Wright's play, the first one-man show ever to receive a Pulitzer Prize, plus two Tony Awards, two Drama Desk Awards, three Obie Awards to list just the most important ones I Am My Own Wife won in 2004, "seems to stem from its foregrounding of the work of historical and personal construction. Perhaps 


\section{HANA PAVELKOVÁ}

there is a pervasive need not simply to see actual lives interestingly deployed on stage, but also how those lives both expose and burry fact" (Schiavi 205). Another factor, which might have influenced the overtly positive reception of I Am My Own Wife is that it addresses questions troubling the spectators of docudramas, which in 2004 enjoyed their heyday. It has been described as "a theatrical essay, about the importance of recording history, that ends up challenging the reliability of all historical narratives, including its own" (Wright 1).

Though I Am My Own Wife is again based on a real character and events, what is at play there is not so much the facts, but how they are remembered. The previously silenced narrator is given the first chance to speak, but it is not a coherent narrative, but a highly dubious fragmentary version of his/her life experience and trauma that gets out of his/her control. Given the hermetic, excluding nature of a monologue, the members of the audience have no way of verifying what the speaker says. At the same time, however, they are able to understand the nature of the character, since what the character evades, lies about or vehemently refuses to say is as revealing as what he/she actually tells us.

In I Am My Own Wife the character who appears from darkness with an enigmatic smile wears a black skirt, rimmed with peasant piping at the hem, a black blouse with short sleeves, black orthopaedic shoes, a delicate string of pearls, no makeup, and his/her hair is covered with a scarf (Wright 4). The playwright links the gender of the monologist with his/her deceptive stories and forces the viewers "to read gender-under-construction rather than see gender-as-given" (Schiavi 202). In I Am My Own Wife the costume designates not the character's inside, which remains a mystery, but the seductive surface. The costume is a demonstration of not only Charlotte's open transvestism, but metaphorically, also of the different guises he/she had to adopt to survive Nazism and Communism. Given the historical context of the play, crossdressing might be understood "as a norm, not an exception" (Wright xix). Consequently, to quote Schiavi again, "the viewers, (after) having perceived the anatomical truth beneath her feminine garb, must proceed to active assessment of her life's truth" (203). Furthermore, the costume also has a very practical function: it suggests the multitude of other characters of both genders the actor impersonates in the play. Wright explains, "[e]veryone from the callow playwright (me) to the fiercest Nazi officer would wear a skirt. How very democratic! I Am My Own Wife would be a one-woman show, performed by a man" (Wright xix). 
Wright's monodrama does not provide an easy reward for the audience. He uses the monologue not to inspect the inner life of his protagonist by showing his/her conflicting identities, or merely to tell a fascinating survival story, but, as Schiavi pointed out, "the principal subject of I Am My Own Wife is less the murky life of its protagonist than the construction and reception of biodramatic truth" (Schiavi 196). The breathtaking stories we hear seduce the audience and have the potential to create a captivating play on their own, yet they deceptively only glide smoothly over the surface. "Charlotte's story has a strange twist, one that Wright uses to crank up the final reliability of this bizarre $20^{\text {th }}$ century saga" (Barnes). Consequently, Charlotte "loses credibility with each successive utterance" (Schiavi 196) and thus the play demands that its "spectators actively account for their meaning making. [...] They must evaluate alongside the playwright which of her narratives are credible and to what extent their incredibility may nullify Charlotte's fitness as a biodramatic subject" (Schiavi 203). Wright uses a very clever strategy, he leads the audience the same way he has taken with Charlotte, from the initial fascination via doubts and disillusionment back to respect for the subject's complexity. "Wright's beguiling exercise in audience-participation, in both mirroring and parodying for audiences the mechanics of their own interpretative work is precisely what keeps viewers focused on the ever-lessdependable Fraulein von Mahlsdorf" (Schiavi 209).

The text is composed mainly from the edited transcripts of his interviews, hence the broken English mixed with German used by Charlotte, plus letters between Wright and his friend John Marks. Marks suggested that Charlotte would be an ideal subject for a play by the openly homosexual Wright. The playwright also uses various newspaper quotations, extracts from TV interviews, etc. Such a documentary framework is essential for the effect of shattering our perspective in the second half of the play, when the incriminating Stasi file appears, revealing Charlotte as an active agent of East Germany Secret Police who probably informed on her competitors in the antiques market. Even more shockingly, it is quite possible that she appropriated for her collection also property of deported Jews. How she got hold of their furniture remains very dubious. As Michael Feingold wrote in the review of I Am My Own Wife, "Charlotte is not only not a 'real' woman; she is perhaps not even the woman she says she is. It may be that almost everything she says about her history is not true of her, and perhaps even not true at all" (Feingold). The only thing we get to know is the version of her life that Charlotte probably convinced herself to believe and which Wright recorded 


\section{HANA PAVELKOVÁ}

in many of his interviews with the real Charlotte von Mahlsdorf, born Lothar Bernfelde, who died in 2002.

To conclude, Charlotte's limits as a narrator are visible, though not verifiable, both in the play and in real life. I Am My Own Wife is a portrait of an enigma and neither the audience nor the author is going to know what the truth is. Wright seems to make a case not only for the importance of storytelling in the life of the protagonist, but also asserts that Charlotte's limits as a narrator are crucial to our understanding of her character. As Bruce Weber summarized, "[t]o endure the world, people may lie about themselves or to themselves, and the lies are as important as the truth" (Weber). It is this broader perspective on the mechanisms of communication, on constructing identity, on the complexity and difficulty of verbalization of trauma that makes Wright's play valuable in comparison with the more straightforward message of My Name Is Rachel Corrie or The Vagina Monologues. Yet, by being straightforward these two monologues succeeded in drawing the attention of the public to serious cases of violence and initiated a very important debate. So although not being as emotionally effective as Heather Raffo's Nine Parts of Desire nor as complex as I Am My Own Wife, their success might calm down critics such as Brian Singleton, who expressed a concern that "the monologue formats reveal an anxiety about the theatre as a means of communication" (Jordan 129).

\section{Acknowledgements}

The research for this paper was generously granted and completed within the GAUK project 396211 supported by the Faculty of Arts, Charles University in Prague.

\section{Works Cited}

Barnes, Clive. "See I Am My Own Wife, Please." Ner York Post 4 December 2003. 13 January 2013 <http://www.iammyownwife.com/review_nypost. asp>.

Cooper, Christine M. Worrying about Vaginas: Feminism and Eve Ensler's The Vagina Monologues. Chicago: The University of Chicago Press, 2007.

D’Monté, Rebecca. "Voicing Abuse, Voicing Gender." Monologues - Theatre, Performance, Subjectivity. Ed. Clare Wallace. Prague: Litteraria Pragensia, 2006. 208-32.

Davies, Walter A. Art and Politics Psychoanalysis, Ideology, Theatre. London: Pluto Press, 2007. 
Donnison, Jon. "Rachel Corrie: Court Rules Israel Not At Fault for Death." BBC Newes 28 August 2012. 13 January 2013 <http://www.bbc.co.uk/news/ world-middle-east-19391814>.

Doug, Wright. I Am My Own Wife. New York: Faber and Faber, 2004.

Ensler, Eve. The Vagina Monologues. New York: Villard, 2001.

Feingold, Michael. "Unnerving Berlin: Doug Wright Quills Up a Transvestite Mythmaker."

The Village Voice 3 June 2003. 13 January 2013 <http://www.villagevioce.com/ content/printVersion/175938.html>.

In Yer Face Theatre, "Experiential theatre." In Yer Face Theatre n.d. 10 January 2013 <http://www.inyerface-theatre.com/az.html\#e>.

Jordan, Eamonn. "Look Who's Talking, Too: The Duplicitous Myth of Naïve Narrative." Monologues - Theatre, Performance, Subjectivity. Ed. Clare Wallace. Prague: Litteraria Pragensia, 2006. 125-157.

My Name Is Rachel Corrie. Ed. Alan Rickman and Katharine Viner. London: Nick Hern Books, 2006. New York Theatre Workshop. "About us." New York Theatre Workshop n.d. 10 January 2013 <http://www.nytw.org/about.asp>. Rebellato, Dan. "Because it feels fucking amazing: Recent British Drama and Bodily Mutilation." Cool Britannia? British Political Drama in the 19gos. Ed. Rebecca D'Monte and Graham Saunders. New York: Palgrave Macmillan, 2008. 192-207.

Raffo, Heather. Nine Parts of Desire. n.d. 10 January 2013 <http://www.youtube. com/watch?v=NCmq5Krppt>. NOTE: This link to the video no longer on-line.

Schiavi, Michael R. "The Tease of Truth: Seduction, Verisimilitude (?), and Spectatorship in I Am My Own Wife." Theatre fournal. May 2006: 195-220. Weber, Bruce. "Inventing Her Life As She Goes Along." The New York Times 4 December 2003. 13 January 2013 <http://www.nytimes.com/2003/12/04/ theater/theatre-review-inventing-her-life-as-she-goes-along/printversion/ 1357468g.html>. 